\title{
In the beginning was violence: Emmanuel Levinas on religion and violence
}

\author{
Ruud Welten ${ }^{1,2}$ (D) \\ Published online: 19 February 2020 \\ (C) The Author(s) 2020
}

\begin{abstract}
It is the aim of this contribution to question the two conceptions of violence in the later Levinas. One of the face, the other the violence that must be overcome by the face. The article argues that this cannot be understood fully without taking into account Levinas' Talmudic philosophy. By focusing on the notion of trauma in the later work of Levinas, it is argued that Levinas' idea of the human subject is understood as radical vulnerability. This idea is evaluated on the basis of short comparisons with the thinking of Lacan, Žižek and Camus. The claim is made that to Levinas, violence is not a phenomenon to be eliminated by rational ethics, but one that forms the very notion of humanity itself. This is elaborated by showing how the Bible takes on a central role in Levinas' thought.
\end{abstract}

Keywords Emmanuel Levinas · Violence $\cdot$ Trauma $\cdot$ Religion

Without a doubt, the philosophy of Emmanuel Levinas is a philosophy against violence. It is a philosophy after the ultimate violence of the Holocaust; a violence that is not committed against individuals only, but against the dignity of humanity as such. Counter-violence is famously understood by Levinas as the face of the other. The face appeals to my humanity and makes me, and only me, responsible for the suffering of the other. Yet, after the encounter of the face, the subject is no longer able to understand itself as the outcome of his own moral intentions. It cannot even be understood as a guideline for ethical conduct. To Levinas, the face is not the bringer of peace, but of anarchy. It commands in a disturbing way. The face disturbs the order of the ego in a violent way. Isn't it counter-intuitive to understand the face as violence, since, according to its original ethical claim, it exactly overcomes

Ruud Welten

r.b.j.m.welten@uvt.nl

1 Faculty of Philosophy, Erasmus University Rotterdam, Burgemeester Oudlaan 50, 3062 PA Rotterdam, The Netherlands

2 Department of Philosophy, School of Humanities, Tilburg University, Warandelaan 2, 5037 AB Tilburg, The Netherlands 
violence? Is violence indeed conquered by the face of the other, and if so, isn't this conquest only possible because of its violence? Is the face-unbearable as it seems to be-the necessary evil which makes me ethical? In other words: Is ethics as first discipline the solution to violence or is it rather the cause? So regarding Levinas, it seems that we have to deal with at least two notions of violence. One of the face, the other the violence that must be overcome by the face.

It is my aim to question these two conceptions of violence in the later Levinas. And as will become clear, this cannot be understood fully without taking into account Levinas' Talmudic philosophy.

\section{Trauma}

The face of the other is exactly not a tender appeal of love, but - as far as the subject is understood as a self-constitutive power-a violence that injures the subject. It is, in terms of Levinas' later work Otherwise than Being a trauma. The use of the word "trauma" strikes us. Why such a psychoanalytic term? To begin with, trauma means simply "wound" in Greek. The subject is to Levinas not a thing that thinks and that looks around in order to notice others: it is primarily vulnerable. Being vulnerable means simply that it can be touched and wounded. In other words, the subject is not that much a bearer of intentionalities, rather it is there to be injured.

I want to emphasize that Levinas only became aware of the traumatic character of the subject in his later work, especially in Otherwise than Being, and I am inclined to follow those commentators who privilege Otherwise than Being over Totality and Infinity. ${ }^{1}$ That is to say, things become much clearer when we take seriously Levinas" "beyond" (au-delà) in the title of his mature work. Certainly, the "beyond" stands among other things for transcendence that evades encapsulation into any totalitarian kind of metaphysics. Levinas complaint against "Western thought" is that it never succeeded in understanding what transcendence is. It is this misunderstanding that in itself already is a violence. For Levinas, Husserlian phenomenology is such a metaphysics that must be exceeded. It is not my aim here to judge whether Levinas is right in his claim about Husserl. Even if it turns out to be false, the "happy mistake" (as Hegel would call it) is nevertheless constitutive for Levinas' entire philosophy. Having said this, Levinas tries to exceed Husserl for at least two reasons: first, because Husserl's conception of time consciousness at the end recuperates everything beyond the horizon of the now. Future becomes the image of future; the past becomes an idea of the past. In other words: the sphere of otherness - that which reaches beyond the image - is there to be reduced to what Levinas calls "the Same". Second, Husserl's notion of intentionality implies a direction of consciousness toward the world and the other. Levinas radically reverses this direction of intentionality: my responsibility for the other cannot be understood as a result of a decision on my account. It concerns an intentionality that envisages me, instead of the other way around.

${ }^{1}$ Cf. Critchley (2007, p. 62). 
This criticism is crucial for our topic of violence. Violence is not a phenomenon as such, but rather the painful lack of any phenomenality. It is "beyond" phenomenology. Of course, it must be conceded that many unfortunate people in the world of course experience violence. But the question is how we have to understand the phenomenological nature of this experience. It is not only a non-intentional experience, it is marked by the inability to make it into an image or concept. "You cannot imagine," or "I don't have words for this" are in fact adequate expressions to "describe" a violent event. In other words, there is something undeniably traumatic in the experience of violence. There is a kind of "experience" of the trauma indeed, but it is an experience that is not shielded by imagination. So, Levinas' philosophy is exactly not a "phenomenology of the ethical experience," but rather the opposite. In my encounter with the face of the other, this "ethical experience" is taken away from me.

As a consequence, the face is a non-experience that cannot be integrated anyhow in any form of discourse: "For in discourse it would have already lost its traumatic violence." ${ }^{2}$ We might think here of what Slavoj Žižek writes about the trauma: "Every very attempt to 'reproduce the facts' in a documentary way neutralizes the traumatic impact of the events described. (...) If the victim were able to report on her painful and humiliating experience in a clear way, with all the data arranged into a consistent order of exposition, this very quality would make us suspicious." 3 Trauma, I repeat, is the lack of experience, the lack of any adequate representation, image or narrative of what has happened. Isn't violence, taken from a phenomenological view, exactly that part of experience that goes beyond experience itself? And how does phenomenology methodologically cope with this lack? Let us read Levinas: "What is exceptional in this way of being signaled is that I am ordered toward the face of the other. In this order which is an ordination the non-presence of the infinite is not only a figure of negative theology. All the negative attributes which state what is beyond the essence become positive in responsibility, a response answering to a non-thematizable provocation and thus a non-vocation, a trauma." 4 It is a negativity, but certainly not one that leaves the subject indifferent. The face of the other does not offer me anything, it takes something away. And now it comes to me. It is this second "me" that is the subject. But it is not the subject with a ground (arche) or rational origin. It is a "me" that is, in the very terms of Levinas, persecuted. The other leaves a wound in subjectivity. Wouldn't it be even more apt to say that subjectivity always presupposes this wound? The "negativity" disturbs, I cannot get a grip on it. It leaves me sleepless. Levinas speaks here of a violence in the pain that awakens, that is to say, instructs and educates and tests..$^{5}$

Terms like "hostage" and "obsession" are not based on the unveiling of any ontological or phenomenological status, but that nevertheless constitute the subject. Levinas uses "psychoanalytical" terms like "trauma", "obsession", (what to think

\footnotetext{
2 Levinas (1998a, b, p. 116).

3 Žižek (2013, pp. 23, 24).

4 Levinas (1991, pp. 11-12).

5 Cf. Goldwyn (2015, p. 41).
} 
of "substitution") in order to suggest that there is something that psychoanalysis is not able to deal with: transcendence, or the experience of the other. It is the appeal of the other that is traumatic to the subject. Yes: to the subject. We have to change our perspective regarding the use of the word trauma in Levinas: it is not the other who is marked by a traumatic experience that makes me responsible for him or her, instead, it is me that is traumatized by the suffering of the other. It is the other who destroys not only the image I have of him but even the image that I used to have to myself. "The face of the Other at each moment destroys and overflows the plastic image it leaves me, the idea existing to my own measure and to the measure of the ideatum - the adequate idea." 6 The face here introduces a notion of truth that is neither the result of a logical reasoning nor of a scientific research. It does not construct anything, as the quote says: it destroys, in terms of Otherwise than being, it destructs, disturbs, traumatizes.

It is this phenomenological gap, this abyss, that makes me irreplaceably responsible. Responsibility is not to be understood as "responsible for this or that", but as subjectivity itself. And this is what it takes when it comes to responsibility: It all comes to me. Responsibility is not something that can be shared (in a Levinasian frame, a notion like "collective responsibility" is a paradox, since the sharing of responsibility would immediately destroy responsibility). But you are not responsible in such a way, that you know what to do. (Kantian ethics for instance, tries to fill in this "not knowing". Ethics, then, becomes reasonable.) This is why Levinas often speaks of anarchy, not referring to a political context, but to the lack (an-) of any arche. As Levinas proclaims, "Anarchy is not disorder as opposed to order." ${ }^{\text {" What }}$ is violated here, is my alleged subjectivity; my ability to deal with the situation. It forces me to go beyond everything that can be organized by understanding or knowledge. Yet, it is important to keep in mind that Levinas is not commenting upon certain "traumatic" situations, although it is true that the Holocaust is without a doubt the drive behind his philosophy. What Levinas has in mind is the deconstruction of the Western ego, not the encounter with difficult people in horrible situations. Judith Butler makes this clear when she comments: "It is important to note here that Levinas is not saying that primary relations are abusive or terrible; he is simply saying that at the most primary level we are acted upon by others in ways over we have no say and that this passivity, susceptibility, and condition of being impinged upon inaugurate who we are." 8

Isn't this exactly what the face "reveals" for Levinas: not meaning or guidance but rather the absence of knowing what to do? What is traumatized by Levinas is the modern self-understanding Western subject: the "I think therefore I am," or the "I know who I am and I know what to do." In short: what is attacked by Levinas' philosophy, is the Western, Greek ideal of "Know Thyself" (Or at least what one has made of it. Don't forget that the Greek discourse on "Know Thyself" stresses the complete incomprehensibility of the Thyself.) To Levinas, philosophy is neither

\footnotetext{
6 Levinas (1979, p. 51).

7 Levinas (1991, p. 101).

8 Butler (2005, p. 85).
} 
about "knowing", nor about "Thyself". Ethics is not the answer to the question about "what the right thing is to do." And this is disturbing. Not only because it disturbs our view on subjectivity, but also because it unmasks the entire Western notion of the subject. The concept was leading for the development of Western culture. The consequences were disastrous. Hence, the claim "I Know Myself" appears as a dangerous lie, like the Sartrian phenomenon of Bad Faith. Levinas is particularly suspicious of the Self. And this is the violent, traumatic part: in the philosophy of Levinas, the subject doesn't "know" itself, rather its alleged knowing is debunked. The subject is nothing but an open, even painful wound. Neither Aristotelian virtues, nor Kantian Pure Reason is there to heal it. In this sense, Levinas certainly is a thinker of destruction, although not in a Nietzschean way. In Levinas, we hear the voice of a much older, original thought, which is the voice of the Torah.

That there is a lack of foundational experience implies that the Husserlian concept of intentionality, in which consciousness is already on the side of the subject, falls short. Consciousness would be the bearer of the ego, the flag-bearer of responsibility. But to Levinas, responsibility is not an object to be "taken" by a subject. We do not "take responsibility" like we take the nine o'clock train or a cup of coffee. It is shouted out toward us, unasked. It is a scream; a cry that cannot be denied, even if we want to. To Levinas, the subject is the passive consciousness that is facing its responsibility, obsessed by the scream. It is the inevitability of responding the scream.

In this respect, notwithstanding his personal rejection of psychoanalysis, Levinas comes close to the psychoanalytic thought of Jacques Lacan. It is true that there is an unbridgeable gap between Levinas and psychoanalysis, and yet they share the idea that a trauma is primarily a lack of representation. To both Levinas and Lacan, the point is that the subject is never what we think it is. Consciousness does not coincide with subjectivity. It is not the self-confident ego that claims to be autonomous and, as a result of this claim is responsible. Before we can speak of a self who is capable of choice, we must consider how that self is formed. ${ }^{9}$ Levinas is close to Lacan here, for whom the subject is never already there, but rather understood from an original split. The subject, so to say, is anything but a "whole," a "oneness." Where traditional metaphysical thought tries to heal this gap (Kant), Levinas and Lacan emphasize this original loss. For Levinas, this means that we can only seriously talk about a subject, when it is touched, awaken, appealed and wounded by the other. ${ }^{10}$

\footnotetext{
9 Cf. Butler (2005, p. 85).

${ }^{10}$ Cf. David Ross Fryer, The Intervention of the Other: Ethical Subjectivity in Levinas and Lacan (V. Laroy); Sarah Harasym (ed.), Levinas and Lacan: The Missed Encounter, SUNY Press, 1998; Simon Crithley, Ethics-Politics-Subjectivity, Derrida, Levinas and Contemporary French Thought, Verso 1999; David Ross Fryer, The Intervention of the Other: Ethical Subjectivity in Levinas and Lacan, New York: Other Press, 2004; Guy-Félix Duportail, Intentionnalité et trauma. Levinas et Lacan, L'Harmattan, 2005; Edith Wyschogrod, Crossover Queries. Dwelling with Negatives, Embodying Philosophy's Others, New York: Fordham University, 2006; Mari Ruti, Between Levinas and Lacan Self, Other, Ethics, Bloomsbury Publishing 2015.
} 


\section{Torah or death}

Let us consider this violent scream with the subject of modernity as its victim. It is a scream, that comes always from outside. It never comes from within (contrary to moral "conscience"). In this sense, the subject doesn't have a content, otherwise than its phantasmagoric "ego." But contrary to Lacan "split subject," the subject is capable of affectivity, that is: to receive, up to injury. It is the other that appeals to me. Is this uninvited visitation, this cry from the other, not precisely the demand of the unconditional God in the Torah? It is important to note here that this "destruction" of the ego is nothing else than what, generally speaking, religion has to offer: You think you're something, but only the Other, God, really has a meaning to offer. It is the Other who throws signification at me. Meaning is never found within; in the "Self" (in a Levinasian frame it is utter nonsense to "follow your heart"). This, in a nutshell, is Levinas' project: to show that meaning isn't something interior (following Augustine), something to be found in the soul, but that it is radically exterior. This is what transcendence conceives. That is to say, the subject doesn't find a confident basis in the Self, but it is constituted by alterity. This is a philosophical, phenomenological analysis, at the same time, Levinas shows that Judaic religion is better aware of this, better than any other "cultural" relation to the world and to others.

As long as God is a theological or philosophical concept, an outcome of our intentionality, there is nothing to fear (this is why revelation in the Bible often goes with "have no fear," exactly because there $i$ s something to fear: something/someone is coming from outside, something alien, something you are not familiar with, someone that might hurt me). Religion is not a set of conventions to be believed, as the modern subject envisages. Intentionality is on the side of the modern subject, regarding itself as a "believer." But, as Pascal famously reminds us to a phrase from the Bible, the God in the Torah evades from such a thematization: "Moreover, he said, I am the God of thy father, the God of Abraham, the God of Isaac, and the God of Jacob. And Moses hid his face; for he was afraid to look upon God (Ex 3:3)." Note the role of fear in the quote and note how the face is the opposite of something to be revealed. But it is a revelation that cannot be understood as a result of intentionality.

So, there is certainly something to fear when it comes to the face. Moreover, the face is unbearable. To go back to Exodus 33, it is not only Moses who hides his face behind his hands. The face of God is not to be seen directly, as (among other verses) Exodus 33 teaches: "Thou canst not see my face: for there shall no man see me, and live. And the Lord said, Behold, there is a place by me, and thou shalt stand upon a rock: And it shall come to pass, while my glory passeth by, that I will put thee in a clift of the rock, and will cover thee with my hand while I pass by: And I will take away mine hand, and thou shalt see my back parts: but my face shall not be seen (Ex 33:20-23)." The verse is discussed at the end of Levinas' kernel text "Meaning and Sense": "The God who passed is not the model of which the face would be an image. To be in the image of God does not mean to be an icon of God, but to find oneself in his trace. The revealed God of our Judeo-Christian spirituality maintains all the infinity of his absence, which is in the persona "order" itself. He shows himself only 
in his trace, as is said in Exodus 33." "11 The face gives us no clue, it is not a "sign." Signs are elements of language and language is there to speak about things. Language is of what Levinas discusses as "the said." Language can only say things that are already said. But the face speaks in a way that precedes language. This preceding is understood as a trace. It is what Levinas describes as the "saying."12 The face speaks, but not because the words that come from the mouth. Instead, meaning is not generated by language itself, but by the appeal that can only be described as a trace. It is a trace because it is the non-representation of something absent. The face is a trace, not a gift of meaning. The face, therefore, always already as a mystery, a riddle, an obsession even, just like in my example of the crying other. ${ }^{13}$

Note that Exodus 33 is quoted by Levinas in one of his philosophical texts, not in his so-called Talmudic lessons, strictly separated by some academics from "the real philosophical stuff." It is simply not true that the work of Levinas can be divided into two strictly separated parts, the one philosophical and the other Talmudic. Rather, Levinas is a Talmudic thinker par excellence and-to put it in terms of another "Talmudic thinker" Jacques Derrida (think only of Glas, designed as a Talmudic scroll) - it is in the marge of the philosophical text where religion as text appears. Although it makes sense to understand the face in Levinas as a phenomenological answer to the violence of Sartre's look, the Levinasian face cannot be understood without the transcendence that goes far beyond (au-delà) any strict "philosophical" argument. ${ }^{14}$ In order to take Levinas seriously as a philosopher, one cannot just skip the numerous references to the Bible. And this is particularly true for his so-called "philosophical works." Levinas incessantly emphasizes the Bible's universal appeal. To Levinas, it is the story of the Revelation on the Sinai which constitutes man, rather than the event of Descartes', "I think therefore I am-don't tell me wat to do."

To Levinas, phenomenological revelation is always already understood as the ultimate Revelation, which is the Revelation on the Sinai. In one of his Talmudic Readings Levinas writes: "At the foot of Mt. Sinai, the Torah was imposed through violence," writes Levinas. ${ }^{15}$ And: "And they stopped at the foot of the mountain... Rav Abdimi bar Hama ba Hasa has said: This teaches us that the Holy One, Blessed be $\mathrm{He}$, inclined the mountain over them like a tilted tub and that He said: If you accept the Torah, all is well, if not here will be your grave."16 Apparently, Revelation is not the object of free choice. "What wonderful circumstances in which to exercise one's free will," Levinas comments. "The negative freedom of those set free is about to transform itself into the freedom of the Law, engraved in stone, into a freedom of responsibilities." 18

\footnotetext{
${ }^{11}$ Levinas (1987, pp. 106-107).

${ }^{12}$ Levinas (1991, pp. 45-47).

13 Cf. Levinas (1987, "Phenomenon and Enigma', pp. 61-74).

${ }^{14}$ According to Sartre, it is the look of the other that deprives the subject of its radical free-floating consciousness.

15 Levinas (1990b, p. 39).

16 Levinas (1990b, p. 37).

${ }^{17}$ Levinas (1990b, p. 37).

${ }^{18}$ Levinas (1990b, p. 37).
} 
Slavoj Žižek is undoubtedly right when he proclaims that "in the Jewish tradition, the divine Mosaic Law is experienced as something externally, violently imposed, contingent and traumatic." He calls it "ethical violence at its purest," exactly because it is a picture of subjectivity that is the opposite of what he calls the "New Age Gnostic problematic of self-realization or self-fulfillment." ${ }^{19}$ In this respect (and against his own intention), Žižek is in line with Levinas. This "New Age Gnostic problematic of self-realization or self-fulfillment" is nothing but a modern fata morgana of freedom. Levinas' idea of freedom is unlike the freedom of modern, western humanity. It is the subject itself that is submitted to a voice that sets him free. Or better: Revelation is a reminder precisely of this consent prior to freedom and nonfreedom. ${ }^{20}$ This is what Levinas described as "difficult freedom." ${ }^{21}$ Levinas affirms: "The teaching, which the Torah is, cannot come to the human being as a result of a choice. That which must be received in order to make freedom of choice possible cannot have been chosen, unless after the fact. In the beginning was violence." 22 No religious Revelation without force. But it is the subject's misconception of freedom that is violated. Against the "easy" freedom of liberalism, there is the "difficult" freedom of Judaism. The primordial violence is the violence of the God that commands, but what He commands is my freedom, which is there to be taken as responsibility. For Levinas, violence must be understood as revelatory in the form of a reminder of the consent prior to freedom and non-freedom. In other words, freedom is exactly not understood as the ultimate possibility to account for our own choices. In words of Judaism, it is not us who choose, but we are being chosen. As Levinas writes in this respect of the "violence of the choice," 23 that might be understood in a double sense: I am being chosen without any "wish" from my side. And this "Goodness" is always older than choice, as far it concerns my choice. The subject is totally delivered to Goodness. So, there is a choice, but the choice doesn't follow the direction of the Husserlian intentionality, that is, from me to a desideratum. It is not me that decides to be responsible for the other. This would be nothing else than a colonialist style of responsibility. The colonialist who takes himself responsible for the well-being of the colonized exactly constitutes his colonialist power by "taking his responsibility." Responsibility here takes the shape of enslavement. "Taking responsibility" in this way is not ethical but rather a strategy of taking power. The paradox here is that ethics is never "my" ethics, but ethics imposed by the other. This is why Levinas stresses the diachrony between the I and the other. This doesn't give the other any possibility to misuse his demand. It would be a false argument to claim that since to the other I am the other, the other, on his turn, has to obey my demand. Levinas is not Hegel: it is not a dialectical relation. Levinas' answer is quite simple: whether the other is at his turn responsible for me, that's his business. The real point here is that it isn't business at all: ethics is not economy. No exchange of services.

\footnotetext{
19 Žižek (2006, p. 140).

${ }^{20}$ Levinas (1990b, p. 39).

21 Levinas (1990a).

22 Levinas (1990b, p. 37).

23 Levinas (1991, p. 57).
} 
From a liberal perspective, Levinas' demand can only be understood as violence. And indeed: it is an ethical, even religious violence. But we have to understand what "religion" is to Levinas.

Religion must be understood as the appeal that is described in the passage in Exodus, rather than the "belief in" a God. To Levinas, religion is exactly not understood as believing in a certain god or entity, even not in the other. Religion is nothing but the appeal of the other that is constitutive of humanity. Already in Totality and Infinity, religion is understood as relation. ${ }^{24}$ Humanity cannot be understood without revelation. Therein lies the kernel of Levinas' entire work: Revelation, the face, cannot be reduced to phenomenology without its Biblical connotations. Revelation does not refer to any imaginary order, but to the traumatic encounter with the other. Strictly speaking, there is no such a thing as a phenomenology of revelation. Revelation, in all its Biblical connotations, requires a completely new notion of phenomenology: A "non-intentional" phenomenology. 25

To Levinas, religion does not consist of theology or God-science (in which "God" is a theme). God is exactly what cannot be reduced to a mere concept or idea. But we are incessantly inclined to do so. Levinas describes this the "temptation of the temptation." Temptation is the desire to know, in contrast to "a wisdom which knows everything without expecting it." 26 To know is always the desire to know, a desire that, in the end, desires itself. Philosophy is always in danger of this temptation. Levinas sketches a wisdom that has not the character of such an intentionality. In fact, he does not tell anything new, because it is nothing more than the age-old Jewish critique of making images, that is, of idolatry. Levinas is a thinker of anti-idolatry.

Idolatry means at least two things here: first, it is making images of the other who resists being reduced to an image and second, it is the attempt to make your own god. Levinas is anti-modern here indeed. The modern believer is a phenomenologist par excellence: he desires experience first in order to be religious later. But as we have seen, the face of the other is everything but the long-awaited foundational experience. It is, again, traumatic.

It is no surprise that Levinas wrote a book entitled Of God who comes to an idea. ${ }^{27}$ God is exactly the idea of the not-yet (or: messianism is a relation towards the not-yet). God doesn't come to mind by knowledge or understanding. God is not something signified, but a signifier, in an absolute way. He signifies in an active way, which means: He orders. As Levinas writes: "Philosophical discourse must, therefore, be able to embrace God_-of whom the Bible speaks—if, that is, this God has a meaning. But once thought, this God is immediately situated within the 'gesture of being.' He is situated therein as a being par excellence. If the intellection of the Biblical God—-theology_does not reach the level of philosophic thought, it

\footnotetext{
24 "For the relation between the being here below and the transcendent being that results in no community of concept or totality—a relation without relation—we reserve the term religion" (Levinas, 1979, p. 80). Cf. 'Is ontology fundamental?', in Entre Nous, London/New York: Continuum 2006, p. 7.

${ }^{25}$ Cf. Levinas (1998a, pp. 123-132).

${ }^{26}$ Levinas (1990b, p. 34).

${ }^{27}$ Levinas (Levinas 1998b). The connotation with idolatry is lost in the translation "Of God Who Comes to Mind."
} 
is not because theology thinks God as a being without making clear to begin with the "being of this being," but because in thematizing God (alterity), theology has brought him into the course of being, while the God of the Bible signifies in an unlikely manner the beyond of being, or transcendence. That is, the God of the Bible signifies without analogy to an idea subject to criteria, without analogy to an idea exposed to the summons to show itself true or false." 28

\section{The violence of the "self"}

Note that "God" is defined here only as the One of whom the Bible speaks. There is no such a thing as a personal-choice God, a God that fits me, that is, in short, the fulfillment of my intention; an idol. God is neither a thing or a being, nor a theme, but comes to mind by withdrawing himself from the realm of ideas. This is why the God of the Torah is not a God who comforts and appeases, but a demanding God who orders, accompanied by thunderclouds. No wonder that Moses and the prophets initially want to get rid of their elections. To Levinas, violence must be understood ultimately as a violence against the Torah: "The Torah itself is exposed to danger because being in itself is nothing but violence, and nothing can be more exposed to violence than the Torah, which says no to it." 29

To Levinas, it is crucial that religion as Torah presents itself here in the form of a book. As might be clear by now: religion is not an experience first, in order to be cultivated in rites and traditions later. One might object: "Well, if religion is a book, it has the same shape as philosophy, words, and arguments. And it is about arguments, we can argue against the violence that is imposed on us." The easiest objection would be that religion is not about words and arguments. But to Levinas, this would present a false, naive portrait of what religion is. Religion would be something like an "inner feeling." According to Levinas, Judaism has nothing in common with mysticism; with an experience that precedes and determines religion. For Levinas, there is no such a thing as a foundational "religious experience." That is why it is correct to say that Levinas' conception of religion is not phenomenological. As said, it is beyond phenomenology. The face is exactly the traumatic absence of any foundational experience (remember how to Husserl phenomenology was understood as a search for a foundational experience). Judaism is described by Levinas as a "religion for adults," not for those who fail to think. ${ }^{30}$ The no of the Torah is not a written prohibition as such, but the ultimate description of the prohibition that resists every kind of intentionality.

From a phenomenological view, religion, then, is counter-intentionality. ${ }^{31}$ It is this "counter-" where the violence must be sought. This is why religion, at least according to Levinas, never can be understood as a matter of "belief," as long as

\footnotetext{
28 Levinas (1998b, p. 57).

29 Levinas (1990b, p. 39).

${ }^{30}$ Levinas (1990a, pp. 11-23).

31 Cf. "non-intentionality”, Levinas (1998a, pp. 123-132).
} 
belief is understood as a mode of intentionality. "The sentence in which God comes to be involved in words is not "I believe in God." ${ }^{32}$ Let me take a detour here by quoting historian and Old-Testament scholar Sigmund Mowinckel, who wrote extensively on the Psalms: "It may often look as though the initiative lies with the congregation, on the human side. But seen from the point of view of cult and religion it is rather the other way round: the initiative lies with God. True enough, it is man that 'searches for God,' 'seeks God,' but he can, and he does so, because the deity has first "revealed himself" and thought man where and when how to seek him." ${ }^{33}$ The quote makes perfectly clear what a phenomenology of religion must describe: not the intentionality of the so-called "believer" (claiming to "belief" in God or not) but man as being the object of God's search. This is where the classic phenomenological scheme of intentionality fails (no wonder that Michel Henry, although focused on Christianity and not on Judaism shares with Levinas his critical stance against Husserl).

Does this make Levinas a rabbi, a prophet? Certainly not. Of course, Levinas is a philosopher, arguing with and against other philosophers, like Descartes, Husserl, and Heidegger. Hence, the idea of what philosophy is, has already been changed as soon it tries to think "beyond" philosophy. To Levinas, philosophy is thinking, but not as a playfield of ideas. A particular being that just takes care of itself, that lives like Spinoza's conatus, is unthinking. ${ }^{34}$ It is the life of the Self, at ease in its Totality. It understands everything. Everything appears as its object, waiting to be thematized. But, as Levinas says: "What simply lives is thus ignorant of the exterior world." 35 It is marked by nothing but ignorance of what is outside there. Its sensation is mere immanent. Thinking only occurs where there is relation, which means: a relation with someone who cannot be understood or reduced to a mere part of the order of the Same. This is why, to Levinas, thinking is never a thinking of ideas, that is of idols. Ideas as representations are there to grasp alterity, that is, to eliminate the otherness of it. In classic Western thought, the other only appears as a result of representational thinking. The subject is to be understood in its original medieval meaning: it is sub-jectum, subjected to the other. Thinking only starts with submission.

Taken from this perspective, Western metaphysics is grounded in the violence of the Self. It is crucial to acknowledge that Levinas is thinking against the foundation of the modern, Western subject. From Aristotle to the Seventeenth Century rationalists, the subject is understood in terms of a substance. The substance is not only the bearer of subjectivity, it provides it a stable footing, which must be defended. Taken as such, Aristotle's Ethics brings about quite the contrary form Levinas' philosophy: it is a seizure of power, an ethics of self-defense. Classical metaphysics is not able the understand the subject as an original wound, as a "rupture of the same." It remains locked in the cosmos, that is: in Being, without any possibility of hearing what is outside of itself: "Like Aristotelian man, Maimonidean man is a 'being' situated in his place in the cosmos. He is a part of being which does not go outside

\footnotetext{
32 Levinas (1998b, p. 75).

33 (Mowinckel 2004: 16).

34 Levinas (1998a, p. 12).

35 Levinas (1998a, p. 12).
} 
being and in which there never occurs the rupture of the same, the radical transcendence that the idea of inspiration and the whole trauma of prophecy seem to entail in the biblical texts." 36 This is exactly why the later Levinas incessantly uses the word "beyond" (Beyond Being, Beyond the Verse). To Levinas, ethics is precisely not about daily life problems and their solutions, it is always already beyond it. The "beyond" is nothing else than transcendence. Man is this rupture. Ethics, thus, is exactly not a theory that formulates "solutions" to daily-life problems: it is nothing but the name of human subjectivity, more "fundamental" than any ontology, all be it "fundamental" without ground, without any arche.

The task of philosophy is not to build logical orders that represent the world and the other, but to be vulnerable to the cry of the other. To "think," according to Levinas, is to relate oneself to the other. It is always already a response, never a monologue in which truth is proclaimed: "A particular being can take itself for a totality only if it is unthinking. Not that it is wrong or thinks badly or foolishly-it simply does not think. Now we do observe freedom or violence in individuals: for us thinking beings who are aware of the totality, who situate every particular being relative to it and seek a meaning in the spontaneity of violence, this freedom seems to denote individuals who confuse their particularity with the totality." 37

Traditional philosophical ethics does not alleviate this hubris of metaphysics but makes it even worse: as long as it is the Self that decides to be responsible for the other, the Self comes first while the other is already exiled to a second plane. Responsibility, then, is a feint for the sake of the self. Here we meet another meaning of violence, not the violence of the face, but the violence of ignoring the face. The Holocaust is this violence, as Zygmunt Bauman (influenced by Levinas) painfully reminded us, that is not that much the phenomenon to be avoided in Western culture, but the ultimate consequence of it: "Modern civilization was not the Holocaust's sufficient condition; it was, however, most certainly its necessary condition. Without it, the Holocaust would be unthinkable. It was the rational world of modern civilization that made the Holocaust thinkable." 38

\section{Two kinds of violence}

Hence, we have two kinds of violence. One the one hand, there is the original violence of the trauma that is constitutive of the subject, on the other hand, there is a violence that needs to be overcome; let's say, the violence of which the Holocaust is the ultimate low point. But if the first one is original, is it possible to overcome the second? In an early text "Freedom and Command," Levinas writes: "Violent action does not consist in being in a relationship with the other; it is, in fact, an action where one is as though one were alone. Violent action, which appears as direct action, immediate action, in fact, has to be thought of as an action that does not touch the individuality of the one who receives the action, or does not touch his

\footnotetext{
36 Levinas (1994, p.145).

37 Levinas (1998a, p. 12).

38 (Bauman, 2000: 13).
} 
substance." 39 Violence is understood here not that much as "doing harm to someone," but as the tyranny of individualism. Levinas continues: "In other words, what characterizes violent action, what characterizes tyranny, is that one does not face what the action is being applied to. To put it more precisely: it is that one does not see the face in the other, one sees the other freedom as a force, savage; one identifies the absolute character of the other with his force." 40 Taking into account what we have said before, violent action is the disregard of the traumatic, primordial violence. This is less paradoxical than it seems: violent action often occurs where people are trying to defend the "Self" (which is nothing else than the negation of exterior constitution), be it their country or individuality. In this regard, the face is an opposition to this violence. It calls for disarmament. "The opposition of the face, which is not the opposite of a force, is not a hostility. It is a pacific opposition, but one where peace is not a suspended war or a violence simply contained. On the contrary, violence consists in ignoring this opposition, ignoring the face of a being, avoiding the gaze, and catching sight of an angle whereby the no inscribed on a face by the very fact that it is a face becomes a hostile or submissive force." 41

The relationship of these two meanings of violence, the violence of the face of the other, and tyrannical violence of the ego, might be compared with the relation between rebellion and revolution in Albert Camus' classic of existentialist anarchism, The Rebel. ${ }^{42}$ According to Camus, the alternative of the violence of revolution in the Stalinist version of it is not just peace or rest. On the contrary: one must acknowledge the original rebellion that is man, to resist the rebellion that is frozen and regulated and that survives only by committing unavoidable "political" murders. The same can be said of the relation between the tyrannical violence of the ego, that will not be overcome by rational ethics, but by the acknowledgment of the primordial violence of the face.

Yet, it would be premature to conclude that Levinas' human society is a society of only people meeting each other face to face. This would be a false induction from the start, since, as we have seen, there is no such a thing as a direct meeting via the face. The face is not a mediation of the other. Neither is it a "persona," a mask, nor a picture: the face is what Levinas' calls transcendence, constitutive for the subject. We have described the face primarily as a trauma. Society, then, becomes only possible when it is governed by humanity, which at its turn is only possible as face. But it does not find its origin in community: "Between the one I am and the other for whom I am responsible there gapes open a difference, without a basis in community." 43 Peace, then, is not to be understood as a cease-fire, an agreement between subjects but must be understood entirely on my side. It is me who is responsible

\footnotetext{
39 Levinas (1987, p. 18).

40 Levinas (1987, p. 19).

41 Levinas (1987, p. 19).

42 Camus (2000).

43 Levinas (1991, p. 166).
} 
for peace; peace is exactly not something between us. ${ }^{44}$ From the viewpoint of the state or community, peace can only appear as an economic principle, an exchange of conditions.

To Levinas, the state is not there to guarantee the individual subject, whoever it is, by justice, but vice versa: it is the uniqueness of my responsibility that makes any political community possible. (Note that it is not grounded in my subjectivity. It remains anarchic, without any ground. That I am responsible does by no means imply that I can claim justice). Justice, then, is understood not as a tyrannical strategy (which usually ends in revenge, a cry for justice), but as the acknowledgment of the face. In an interview, Levinas proclaims: "If there were no order of Justice, there would be no limit to my responsibility." Levinas continues: "There is a certain measure of violence necessary in terms of justice; but if one speaks of justice, it is necessary to allow judges, it is necessary to allow institutions and the state; to live in a world of citizens, and not only in the order of the Face to Face." Yet, this does not imply that the state is a human order in which the face can be left out. Levinas continues: "On the other hand, it is in terms of the relation to the Face or of me before the other that we can speak of the legitimacy or illegitimacy of the state. A state in which the interpersonal relationship is impossible, in which it is directed in advance by the determinism proper to the state, is a totalitarian state. So, there is a limit to the state. Whereas, in Hobbes's vision-in which the state emerges not from the limitation of charity, but from the limitation of violence-one cannot set a limit on the state." The questioner in the interview asks: "So is the state always the acceptance of some level of violence?" On which Levinas answers: "There is an element of violence in the state, but the violence can involve justice. That does not mean violence must not be avoided as much as possible; everything that replaces it in the life between states, everything that can be left to negotiation, to speech, is absolutely essential; but one cannot say that there is no legitimate violence."45

Hence, it is possible to discern a difference between religious violence and political violence. Religious violence is not violence committed by religious persons (because that is exactly modern, political violence par excellence!) but transcendental, that is, traumatic violence. It is the violence that destructs the rationality of the ego in order to make room for an idea of the subject that is constituted by radical transcendence; which is: by the other.

\section{Stop the killings}

Still, why should one violence be authorized to overcome another violence? Levinas' has a clear answer to this question: the face is conveyed by the commandment "Thou shalt not kill." Although it remains unclear how a Levinasian ethics would look (understood as an answer to the question "what is the right thing to do?") it is clear that the content of ethics is the prohibition of murder. Again, Levinas and Camus arrive at a halt on murder via totally different roads. Like

${ }^{44}$ Cf. Levinas (1991, p. 167).

${ }^{45}$ Levinas (1998a, p. 105). 
Camus (a thinker against murder eminently), Levinas assumes that the primary response to the other is the desire to kill. "The other is the only being whose negation can be declared only as total: a murder. The other is the only being I can want to kill." 46 At first sight, this seems to be strange, since why should we kill in the first place? Why such a philosophy of the prohibition on murder that seems to give an answer to a problem that is presupposed by the very same claim? But to Levinas, the point is that the other is the only thing in the world that is vulnerable to my violence. The other appears to me primarily as the one who I can kill if I want to, or even worse: when I am convinced that I have to. It is therefore that I am responsible for his death in the first place. Again, the non-violence is not an absence of violence, since violence is already there. Levinas' non-violence is nothing but the messianic promise that appears in the tension between the fear of undergoing violence and the fear of causing violence. I can stop this anxiety by killing the other, in other words: I can defend my self-confident ego. This is why to Levinas, the ego of modernity, the ego on which Europe is established, fails. The Holocaust appeared as the "final solution" to an alleged violence committed towards a self-confident nation. "Yet this power is the complete opposite of power. The triumph of this power is its defeat as power." 47 Levinas' ethics is, unlike that of for instance Aristotle, anything but an ethics of power. It is an ethics of vulnerability. Vulnerable to violence. In the Beginning was violence.

Open Access This article is licensed under a Creative Commons Attribution 4.0 International License, which permits use, sharing, adaptation, distribution and reproduction in any medium or format, as long as you give appropriate credit to the original author(s) and the source, provide a link to the Creative Commons licence, and indicate if changes were made. The images or other third party material in this article are included in the article's Creative Commons licence, unless indicated otherwise in a credit line to the material. If material is not included in the article's Creative Commons licence and your intended use is not permitted by statutory regulation or exceeds the permitted use, you will need to obtain permission directly from the copyright holder. To view a copy of this licence, visit http://creativecommons.org/licen ses/by/4.0/.

\section{References}

Bauman, Zygmunt. 2000. Modernity and the Holocaust. Ithaca, NY: Cornell University Press.

Butler, Judith. 2005. Giving an Account of Oneself. New York: Fordham University Press.

Camus, Albert. 2000. The Rebel. London: Penguin Classics.

Critchley, Simon. 2007. Infinitely Demanding. Ethics of Commitment, Politics of Resistance. London: Verso.

Goldwyn, Elisabeth. 2015. Reading Between the Lines. Form and Content in Levinas's Talmudic Readings. Pittsburgh: Duquesne University Press.

Levinas, Emmanuel. 1979. Totality and Infinity. The Hague: Martinus Nijhoff Publishers.

Levinas, Emmanuel. 1987. Collected Philosophical Papers. The Hague: Martinus Nijhoff Publishers.

Levinas, Emmanuel. 1990a. Difficult Freedom. Essays on Judaism. Baltimore: The John Hopkins University Press.

Levinas, Emmanuel. 1990b. Nine Talmudic Readings. Bloomington: Indiana University Press.

Levinas, Emmanuel. 1991. Otherwise than Being. Dordrecht: Kluwer Academic Publishers.

\footnotetext{
46 Levinas (1998a, p. 9).

47 Levinas (1998a, p. 9).
} 
Levinas, Emmanuel. 1994. Beyond the Verse. Talmudic Readings and Lectures. Bloomington: Indiana University Press.

Levinas, Emmanuel. 1998a. Entre Nous. New York: Columbia University Press.

Levinas, Emmanuel. 1998b. Of God Who Comes to Mind. Stanford, CA: Stanford University Press.

Mowinckel, Sigmund. 2004. The Psalms in Israel's Worship. Grand Rapids, MI: Eerdmans Publishing. Žižek, Slavoj. 2006. Neighbors and Other Monsters: A Plea for Ethical Violence. In Neighbor: Three Inquiries in Political Theology. Chicago: University of Chicago Press.

Žižek, Slavoj. 2013. Less Than Nothing. Hegel and the Shadow of Dialectical Materialism. London: Verso.

Publisher's Note Springer Nature remains neutral with regard to jurisdictional claims in published maps and institutional affiliations. 